\title{
Italian Validation of Smartphone Addiction Scale Short Version for Adolescents and Young Adults (SAS-SV)
}

\author{
Concetta De Pasquale, Federica Sciacca, Zira Hichy \\ Department of Education Science, University of Catania, Catania, Italia \\ Email:depa squa@unict.it, federica.sciacca@hotmail.com,z.hichy@unict.it
}

How to cite this paper: De Pasquale, C., Sciacca, F., \& Hichy, Z. (2017). Italian Validation of Smartphone Addiction Scale Short Version for Adolescents and Young Adults (SAS-SV). Psychology, 8, 1513-1518. https://doi.org/10.4236/psych.2017.810100

Received: July 11, 2017

Accepted: August 7, 2017

Published: August 10, 2017

Copyright $\odot 2017$ by authors and Scientific Research Publishing Inc. This work is licensed under the Creative Commons Attribution International License (CC BY 4.0).

http://creativecommons.org/licenses/by/4.0/

\section{c) (i) Open Access}

\begin{abstract}
Objectives: To establish a valid and reliable translated version of Smartphone Addiction Scale for adolescent (SAS-SV) in Italian languages. It is a 10-item, monodimensional, self-administered questionnaire, which was validated using a large Korean sample. Methods: We reported the linguistic validation process and the metric validity of the Italian version of SAS-SV in the Italy. The sample consisted of 633 adolescents and young adults, recruited from High Public School and University in Italy, with a mean age of 18 years. The validation process consisted in forward-backward translation, and factor structure testing. Results: Results showed a good reliability (Cronbach's alpha $=.79$ ) and an almost acceptable factor structure. Conclusion: A valid and reliable Smartphone Addiction Scale in Short Version was developed which can be used for research and clinical assessment of adolescents and young adults with smartphone addiction.
\end{abstract}

\section{Keywords}

Adolescents, Young Adults, Smartphone Addiction, Validation, Scale

\section{Introduction}

In recent decades, the progress of technology has been considerable. The use of internet, smartphones, video games, social networks and other technological tools is very common. Their use is increasingly popular regardless of age, sex, social class and culture (De Pasquale et al., 2015; De Pasquale, Sciacca, \& Fronte, 2016).

Adolescents and children of today are those who experience more this situation, were born in the age of technology and communications virtual/digital and are therefore referred to as "digital natives" (De Pasquale et al., 2011). 
Specifically, cellphone, which now takes the name of Smartphone thanks to its extensive applications and to the integration of the computer's operating system, is a priceless resource that made human life easier allowing distance communication, in which spatial and temporal barriers are eliminated. This has made us slaves of this device. As it always happens when the use of something becomes excessive, the Smartphone could lead to risky behavior. In this regard much research has been conducted on children, adolescents and young adults, on the frequency of use of these technological tools, in particular the wide use of smartphone, about what motivates young people to use (Carlini et al., 2014) and the consequences that these have on them (Haug et al., 2015; De Pasquale, Sciacca, \& Hichy, 2016). Recent literature showed the existence of comorbidity between the use of smartphone, internet addiction, and psychiatric disorders (Elhai et al., 2017; Mohammadbeigi et al., 2017).

Smartphone Addiction Scale (SAS) is designed to identify the level of the smartphone addiction risk and to distinguish the high-risk group (Kwon et al., 2013).

We report the linguistic validation process and the metric validity of the Italian version of the SAS-SV in the Italy, it is useful to collect data about the pathological use of smartphone.

\section{Methods}

\subsection{Sample}

Participants were selected from a High Public School and University in Italy. Adolescents participants were selected after the informed consent granted by the head teacher, while young adults participants were selected in study rooms after theirs informed consent. We were asked them to identify their gender, age, school or university, main use of smartphone. The sample consisted of 633 (282 boys; 351 girls) adolescents and young adults, recruited from High Public School and University in Italy, from March 2016 to April 2017, with a mean age of 18 years. The majority of sample consists in of scientific college students (31.6\%), educational science students (17.5\%), psychology students (23.1\%) and catering collage students (13.6\%). Participants said they would use the smartphone for different aims, as shown in Table 1.

\subsection{Smartphone Addiction Scale}

The SAS-SV is a well-validated specific questionnaire to identify the level of the smartphone addiction risk and to distinguish the high-risk group in adolescent in Korea (Kwon et al., 2013). The questionnaire includes 10 questions describing daily-life disturbance, positive anticipation, withdrawal, cyberspace-oriented relationship, overuse and tolerance. For each item, participants expressed their opinion on a 6-point scale ranging from 1 (strongly disagree) to 6 (strongly agree). It identifies the different range for males and females. Males are addicted 
Table 1. Different use of smartphone of the sample.

\begin{tabular}{cc}
\hline Use of Smartphone & $\%$ \\
\hline Social network & 45.5 \\
Games & 25.4 \\
Internet & 52.5 \\
Call & 60.0 \\
Photo & 37.3 \\
SMS & 60.2 \\
Whatsapp & 97.8 \\
To read book & 0.8 \\
Communication & 1.9 \\
Applications & 2.1 \\
\hline
\end{tabular}

to scores higher than 31, with high risk of addiction with scores between 22 and 31 and females are addicted to scores higher than 33, with high risk of addiction on scores between 22 and 33 (Kwon et al., 2013).

\subsection{Translation and Cultural Adaptation Process}

The original version of the scale was drawn by four Koreans psychiatrists of "The Catholic University of Korea" (Kwon et al., 2013). The linguistic validation of a scale was coordinated by the Italian Researcher, Psychology and Psychiatrist to University.

They developed a translation and the cultural adaptation process and psychometric testing. The work based on two steps. The first were to provide a conceptual definition of the original items to clarify the notions investigated in each item of the original Korean questionnaire, while the second step were to provide a translation and cultural adaptation processes. Forward translation of the SAS-SV from English into Italian was conducted by two native Italian speakers who were also fluent in English, they discussed about difference between two versions and then some terms were reworded. A new Italian translated version of the SAS-SV was produced, as shown in Table 2.

\subsection{Statistical Analyses}

A confirmatory factor analysis was performed using LISREL 8 (Jöreskog \& Sörbom, 1996-2001). The reliability of instrument was calculated through Cronbach's alpha, using the SPSS 24 software (Statistical Package for Social Science).

\section{Results}

\subsection{A Item Analysis and Reliability}

Item analysis of Smartphone Addiction Scale for Adolescent for Italian sample is 
Table 2. Italian version of the smartphone addiction scale for adolescent.

\begin{tabular}{ll}
\hline 1 & Non riesco a fare un lavoro pianificato a causa dell'utilizzodello smartphone \\
2 & $\begin{array}{l}\text { Ho difficoltà di concentrazione in classe. mentre si fanno i compiti o mentre si sta } \\
\text { lavorando. a causa dell'utilizzodello smartphone }\end{array}$ \\
3 & Sento dolore ai polsi. alla schiena o al collo mentreuso lo smartphone \\
4 & Non sarei capace di resisteresenzauno smartphone \\
5 & Mi sento impaziente ed irritabile quando non ho ilmio smartphone \\
6 & Ho ilmio smartphone in menteanche quando non lo sto usando \\
7 & $\begin{array}{l}\text { Non rinuncerei mai all'uso del mio smartphone dalmomentoche la mia vita quotidia- } \\
\text { na è molto influenzata da esso }\end{array}$ \\
8 & $\begin{array}{l}\text { Controllo costante menteilmio smartphone in modo da non perdere le conversazioni } \\
\text { tra le altrepersonesu twitter o facebook }\end{array}$ \\
9 & Usoilmio smartphone più a lungo di quanto dovrei \\
10 & Le persone intorno a me mi dicono che uso troppoilmio smartphone \\
\hline
\end{tabular}

Table 3. Item analysis of smartphone addiction scale for adolescent for Italian sample.

\begin{tabular}{cccccc}
\hline \multicolumn{3}{c}{$\begin{array}{c}\text { Scale Mean }=2.88 ; \\
\text { SD }=.89\end{array}$} & \multicolumn{5}{c}{$\begin{array}{c}\text { Italian sample }(\mathrm{N}=633) \\
\text { Alpha }=.79\end{array}$} \\
\hline & $\mathrm{M}$ & $\mathrm{SD}$ & Item-total correlation & Alpha if item deleted & CFA factor loadings \\
\hline 1 & 2.70 & 1.266 & .339 & .795 & .39 \\
2 & 2.39 & 1.399 & .388 & .790 & .38 \\
3 & 1.67 & 1.121 & .210 & .805 & .25 \\
4 & 3.67 & 1.695 & .586 & .766 & .72 \\
5 & 2.97 & 1.565 & .595 & .766 & .70 \\
6 & 2.32 & 1.318 & .412 & .788 & .58 \\
7 & 3.25 & 1.576 & .606 & .764 & .75 \\
8 & 3.06 & 1.647 & .460 & .783 & .49 \\
9 & 3.88 & 1.549 & .557 & .771 & .55 \\
10 & 2.91 & 1.741 & .513 & .776 & .53 \\
\hline
\end{tabular}

shown in Table 3. Regarding internal consistency all the item-total correlations appeared adequate, and there were no changes in the value of alpha excluding item. Finally, reliability coefficients were high (alpha $=.79)$.

\subsection{Factor Structure}

To test the factor structure of the scale a confirmatory factor analysis (CFA) with one latent factor and ten observed variables (the ten items) was performed (Jöreskog \& Sörbom, 2001). To verify the adequacy of the models we used the $\chi^{2}$ : a solution fits the data well when $\chi^{2}$ is non-significant $(p>.05)$. Given that this statistic is sensitive to sample size. The two-index strategy (Hu \& Bentler, 1999) 
proposing combined use of comparative fit index (Bentler, 1990) and standardized root mean square residual (Bentler, 1995) was applied. The model fits the data well if CFI is greater than or equal to .95 and SRMR is smaller than or equal to .08. Goodness of fit indexes are: $\chi^{2}(35)=258.17 . p<.001$. CFI $=.92$. SRMR $=.062$; as you can see, the SRMR meets completely the criteria, while the CFI is just below it. Moreover, all factor loadings were significant $p<.001$.

\section{Discussion \& Conclusion}

The aim of this study was to test the validity of the Smartphone Addiction scale in Italian languages. The scale possesses a good internal consistency and its monofactorial structure was confirmed.

The SAS-SV in the Italian version is valid although some indices are not perfect. In fact, only one factor has a low saturation. This scale is useful for detecting the degree of Smartphone addiction in adolescents (Lopez-Fernandez, 2015) as prolonged use of the smartphone may have negative effects on different mental and physical health indicators.

The use of this instrument can be an added value to implement the screening process and prevent addiction from smartphone in communities or schools and to monitor risk behavior, predictive mental disorders (De Pasquale, Sciacca, \& Hichy, 2016).

\section{Limits}

The present study has a limitation, the cut-off scores used for the Italian version of SAS-SV were based on the Korean version of the scale and the respective ROC analysis was conducted in a sample of teenagers from Korea.

\section{Acknowledgements}

We thank the participants for their willingness to participate.

\section{References}

Bentler, P. M. (1990). Comparative Fit Indexes in Structural Models. Psychological Bulletin, 107, 238-246. https://doi.org/10.1037/0033-2909.107.2.238

Bentler, P. M. (1995). EQS Structural Equations Program Manual. Encino, CA: Multivariate Software.

Carlini, R., \& Cozzolino, G. (2014). Gliadolescenti e iltelefonocellulare: Ovverol'Affermarsi di un nuovomodellorelazionale. Psychomedia: Memoria e (tele)comunicazione.

De Pasquale, C., \& Gensabella, G. (2011). Il ruolo della comunicazione mediatica e del gioco virtuale nell'infanzia. Unaricercasulleabitudiniedinfluenza. Catania. Annali della facoltà di Scienze della formazione Università degli studi di Catania. pag 123.

De Pasquale, C., Sciacca, F., \& Fronte, V. (2016). Gaming Addiction: An Investigation in Italian Adults in Avola. Psychology, 7, 1248-1255. https://doi.org/10.4236/psych.2016.79127

De Pasquale, C., Sciacca, F., \& Hichy, Z. (2016). Validation of the Italian Version of the Dissociative Experience Scale for Adolescents and Young Adults. Annals of General 
Psychiatry, 15, 31. https://doi.org/10.1186/s12991-016-0120-4

De Pasquale, C., Sciacca, F., \& Hichy, Z. (2015). Smartphone Addiction and Dissociative Experience: An Investigation in Italian Adolescent Aged between 14 and 19 Years. International Journal of Psychology \& Behavior Analysis, 1, 109.

Elhai, J. D., Dvorak, R. D., Levine, J. C., \& Hall, B. J. (2017) Problematic Smartphone Use: Conceptual Overview and Systematic Review of Relations with Anxiety and Depression Psychopathology. Journal of Affective Disorders, 207, 251-259.

https://doi.org/10.1016/j.jad.2016.08.030

Haug, S., Castro, R. P., Kwon, M., Filler, A., Kowatsch, T., \& Schaub, M. P. (2015) Smartphone Use and Smartphone Addiction among Young People in Switzerland. Journal of Behavioral Addictions, 4, 299-307. https://doi.org/10.1556/2006.4.2015.037

Hu, L., \& Bentler, P. M. (1999). Cutoff Criteria for Fit Indexes in Covariance Structure Analysis: Conventional Criteria versus New Alternatives. Structural Equation Modeling, 6, 1-55. https://doi.org/10.1080/10705519909540118

Jöreskog, K. G., \& Sörbom, D. (1996-2001). LISREL 8 User's Reference Guide. Chicago: Scientific Software International.

Kwon, M., Kim, D.-J., Cho, H., \& Yang, S. (2013). The Smartphone Addiction Scale: Development and Validation of a Short Version for Adolescents. Plos ONE, 8, e83558. https://doi.org/10.1371/journal.pone.0083558

Lopez-Fernandez, O. (2015). Short Version of the Smartphone Addiction Scale Adapted to Spanish and French: Towards a Cross-Cultural Research in Problematic Mobile Phone Use. Addictive Behaviors, 64, 275-280.

https://doi.org/10.1016/j.addbeh.2015.11.013

Mohammadbeigi, A., Mohammadsalehi, N., Moshiri, E., Anbari, Z., Ahmadi, A., \& Ansari, H. (2017) The Prevalence of Phantom Vibration/Ringing Syndromes and Their Related Factors in Iranian' Students of Medical Sciences. Asian Journal of Psychiatry, 27, 76-80. https://doi.org/10.1016/j.ajp.2017.02.012

\section{Submit or recommend next manuscript to SCIRP and we will provide best service for you:}

Accepting pre-submission inquiries through Email, Facebook, LinkedIn, Twitter, etc. A wide selection of journals (inclusive of 9 subjects, more than 200 journals) Providing 24-hour high-quality service

User-friendly online submission system

Fair and swift peer-review system

Efficient typesetting and proofreading procedure

Display of the result of downloads and visits, as well as the number of cited articles Maximum dissemination of your research work

Submit your manuscript at: http://papersubmission.scirp.org/

Or contact psych@scirp.org 